\title{
Identifying the contribution of wild and hatchery Chinook salmon (Oncorhynchus tshawytscha) to the ocean fishery using otolith microstructure as natural tags
}

\author{
Rachel Barnett-Johnson, Churchill B. Grimes, Chantell F. Royer, and \\ Christopher J. Donohoe
}

\begin{abstract}
Quantifying the contribution of wild (naturally spawned) and hatchery Chinook salmon (Oncorhynchus tshawytscha) to the mixed-stock ocean fishery is critical to understanding their relative importance to the persistence of salmon stocks. The inability to distinguish hatchery and wild salmon has inhibited the detection of declines or recoveries for many wild populations. By using Chinook salmon of known hatchery and wild origin, we established a baseline for separating these two sources using otolith microstructure. Otoliths of wild salmon contained a distinct exogenous feeding check likely reflecting an abrupt transition in food resources from maternal yolk not experienced by fish reared in hatcheries. Daily growth increments in otoliths from hatchery salmon immediately after the onset of exogenous feeding were wider and more uniform in width than those in wild fish. The discriminant function that we used to distinguish individuals reared in hatcheries or in the wild was robust between years (1999 and 2002), life history stages (juveniles and adults), and geographic regions (California, British Columbia, and Alaska) and classified fish with $\sim 91 \%$ accuracy. Results from our mixed-stock model estimated that the contribution of wild fish was $10 \% \pm 6 \%$, indicating hatchery supplementation may be playing a larger role in supporting the central California coastal fishery than previously assumed.
\end{abstract}

Résumé : La mesure des contributions des saumons chinook (Oncorhynchus tshawytscha) reproduits en nature (sauvages) et en pisciculture à la pêche commerciale marine de stock mixte est essentielle pour comprendre leur importance relative dans la persistance des stocks de saumons. L'impossibilité de distinguer entre les saumons de pisciculture et les saumons sauvages a empêché la détection des déclins et des récupérations chez de nombreuses populations sauvages. En utilisant des saumons chinook d'origine connue en nature ou en pisciculture, nous avons établi des critères de base pour séparer les deux sources d'après la microstructure des otolithes. Les otolithes des saumons sauvages portent une marque distincte exogène d'alimentation qui reflète sans doute une transition abrupte dans les ressources alimentaires après l'épuisement du jaune d'oeuf maternel, ce qui ne survient pas chez les poissons élevés en pisciculture. Les zones de croissance journalière dans les otolithes des saumons de pisciculture immédiatement après le début de l'alimentation exogène sont plus larges et d'épaisseur plus uniforme que celles des poissons sauvages. La fonction discriminante que nous utilisons pour distinguer les individus élevés en pisciculture et en nature est robuste en fonction des années (1999 et 2002), des stades du cycle biologique (jeunes et adultes) et des régions géographiques (Californie, ColombieBritannique et Alaska) et elle classifie les poissons avec un succès de $\sim 91 \%$. Les résultats obtenus dans notre modèle de stock mixte estiment la contribution des poissons sauvages à $10 \pm 6 \%$, ce qui indique que les ajouts provenant des piscicultures semblent jouer une rôle plus important qu'on le croyait antérieurement dans le soutien de la pêche côtière au large de la Californie centrale.

[Traduit par la Rédaction]

\section{Introduction}

The role of artificial propagation in managing fisheries and recovering threatened and endangered populations to sustainable levels is one of the more controversial issues in applied ecology. Are artificially propagated (hatchery) fish effective at recovering depleted stocks or do they actually harm naturally spawned (wild) populations (MacCall 1989; Grimes 1998; Myers et al. 2004)? Impacts of hatcheryproduced salmon on the long-term sustainability and persis-

Received 5 October 2006. Accepted 4 June 2007. Published on the NRC Research Press Web site at cjfas.nrc.ca on 17 November 2007. J19580

R. Barnett-Johnson, ${ }^{\mathbf{1}, 2}$ C.B. Grimes, C.F. Royer, ${ }^{3}$ and C.J. Donohoe. ${ }^{2}$ National Marine Fisheries Service, Fisheries Ecology Division, Southwest Fisheries Science Center, Santa Cruz Laboratory, 110 Shaffer Road, Santa Cruz, CA 95060, USA.

${ }^{1}$ Corresponding author (e-mail: Barnett-Johnson@biology.ucsc.edu).

${ }^{2}$ Present address: Institute of Marine Sciences, University of California, Santa Cruz, 100 Shaffer Road, Santa Cruz, CA 95060, USA.

${ }^{3}$ Present address: Humboldt State University, Forestry and Watershed Management, 1 Harpst Street, Arcata, CA 95521, USA. 
tence of wild salmon have been difficult to assess, although deficiencies have been reported for hatchery progeny (National Research Council (NRC) 1996; Olla et al. 1998).

Ecological effects of hatchery production have received less attention than genetic impacts, in part because of the difficulty in distinguishing hatchery from wild salmon throughout the widespread migratory range characteristic of salmonid populations. This has led to contentious debates over policy decisions on whether to count hatchery salmon along with wild salmon in assessing the endangered designation of populations and the effectiveness of recovering depleted wild stocks by artificial enhancement (Grimes 1998; Brannon et al. 2004; Myers et al. 2004; Araki et al. 2007).

Determining the beneficial and (or) detrimental effects of hatcheries is particularly vital for salmon, as hatcheries remain the cornerstone solution to preserving salmon fisheries, recovering threatened and endangered stocks, and mitigating for overharvesting, habitat degradation, and construction of dams (Hilborn 1992). Knowledge of spatial and temporal variation in the relative abundance of hatchery and wild salmon is key to understanding how these two sources respond to environmental variation, interact, and contribute to their combined population dynamics. If it were possible to distinguish the origin (hatchery or wild) of salmon that return to spawn, it would be possible to $(i)$ determine estuarine and marine survival trends for hatchery and wild fish, (ii) track the decline or recovery of wild populations independently of hatchery supplementation, (iii) detect straying of hatchery fish into breeding grounds of wild salmon, and (iv) quantify potential demographic impacts of hatcheries.

Currently, no traditional tagging methods (e.g., physical or genetic) are sufficient to independently quantify the status of wild salmon from the Central Valley of California (Banks et al. 2000; California Department of Fish and Game (CDFG) 2001). Fall-run Chinook salmon (Oncorhynchus tshawytscha) from the California Central Valley (CCV) alone contribute $85 \%-95 \%$ of the ocean salmon harvest in California, resulting in the $\$ 60$ million in commercial income in the US annually (Pacific Fisheries Management Council (PFMC) 2004). Thirty-five million Chinook salmon are produced annually by four state hatcheries and one federal hatchery in the $\mathrm{CCV}$, which clearly plays an important role in supplementing commercial and recreational fisheries (PFMC 2004). However, because of the historically low and variable use of coded wire tags (CWT) to mark fish in the CCV ( $<10 \%$ of hatchery releases), there are no estimates of the contribution of wild or hatchery fish to the ocean harvest from the CCV (CDFG 2001; Alan Grover, California Department of Fish and Game, Ocean Salmon Project, 475 Aviation Boulevard, Suite 130, Santa Rosa, CA 95403, USA, personal communication, 2001). The overall ocean harvest for central California has remained remarkably stable over the last 10 years, yet it is unclear to what extent the fishery depends increasingly on hatchery-produced salmon (PFMC 2004).

Variations in daily growth patterns or life history transitions recorded in the ear bones of fishes (e.g., otolith microstructure) show great promise as natural tags to differentiate stocks experiencing different growth environments
(Campana and Casselman 1993; Friedland and Reddin 1994; DeVries et al. 2002). Otoliths grow by the daily accretion of calcium carbonate into a proteinaceous matrix, generating a pattern of concentric rings (i.e., increments) around the central primordia. Widths of daily increments laid down in Chinook salmon otoliths are influenced by feeding amount and frequency, water temperature, and photoperiod (Neilson and Geen 1982; Campana and Neilson 1985). We build on previous studies using natural differences in otolith microstructure as tags to identify hatchery and wild Chinook salmon (Zhang et al. 1995; Smith et al. 2006) by determining its generality across years, geographic regions, and thus utility to determine the contribution of wild fish to California's mixed-stock ocean fishery, an application that currently eludes alternative tagging methods.

\section{Materials and methods}

Juvenile Chinook salmon from the fall run were sampled from five hatcheries and eight wild populations (Fig. 1) that include all potential sources of fall run in the CCV to develop a discrimination function (DF). In 1999 and 2002, hatchery-reared juveniles were collected from each hatchery before their release or, in the case of the San Francisco Estuary in 1999, after release and identification by CWT. In both years, wild juveniles were collected from streams with rotary screw traps operated by the California Department of Fish and Game, East Bay Municipal Utility District, or S.P. Cramer and Associates. All wild juveniles were collected before hatchery releases into rivers or on rivers without supplementation.

Adult Chinook salmon of known hatchery origin from the CCV (based on presence of CWT) were collected in the California ocean fishery, as well as from hatcheries when fish returned to spawn, to provide an independent test of the DF. In addition, voucher otoliths from CWT recoveries of Chinook salmon in Alaska of known hatchery (Crystal Lake, Medvejie, and Little Port Walter Hatcheries) and wild (Stikine and Taku rivers) origin were provided by the Alaska Department of Fish and Game. These otoliths were used to determine classification rates particularly of known-origin wild Chinook salmon, as marked wild fish are rare in the California Central Valley and thus could not be used for model assessment.

Collections of adult Chinook salmon (3 years of age) of unknown origin were stratified temporally and spatially from recreational and commercial vessels off the central California Coast. Samples were collected along a broad section of the California coast $(300 \mathrm{~km})$ between Monterey and Point Arena spanning the salmon fishing season from June to October 2002 to estimate the composition of the ocean harvest ( $N=158$; Fig. 1). Fall-run Chinook salmon from the CCV constitute the major contributors to the central California ocean fishery during these months, which minimizes the probability of collecting individuals from other river systems in deriving our estimates (California coastal or KlamathTrinity basin; PFMC 2004; Barnett-Johnson 2007).

Sagittal otoliths were extracted from fish and prepared for microstructure examination per established protocol for salmonids (Neilson and Geen 1982). Sagittae were washed 
Fig. 1. Geographic locations where juvenile Chinook salmon (Oncorhynchus tshawytscha) were collected in rivers (names) and hatcheries (circled numbers) in 1999 (superscript 1) and 2002 (superscript 2). Adults of unknown origin were collected in the mixed-stock ocean fishery off the central California coast from Bodega Bay to Monterey Bay in 2002.

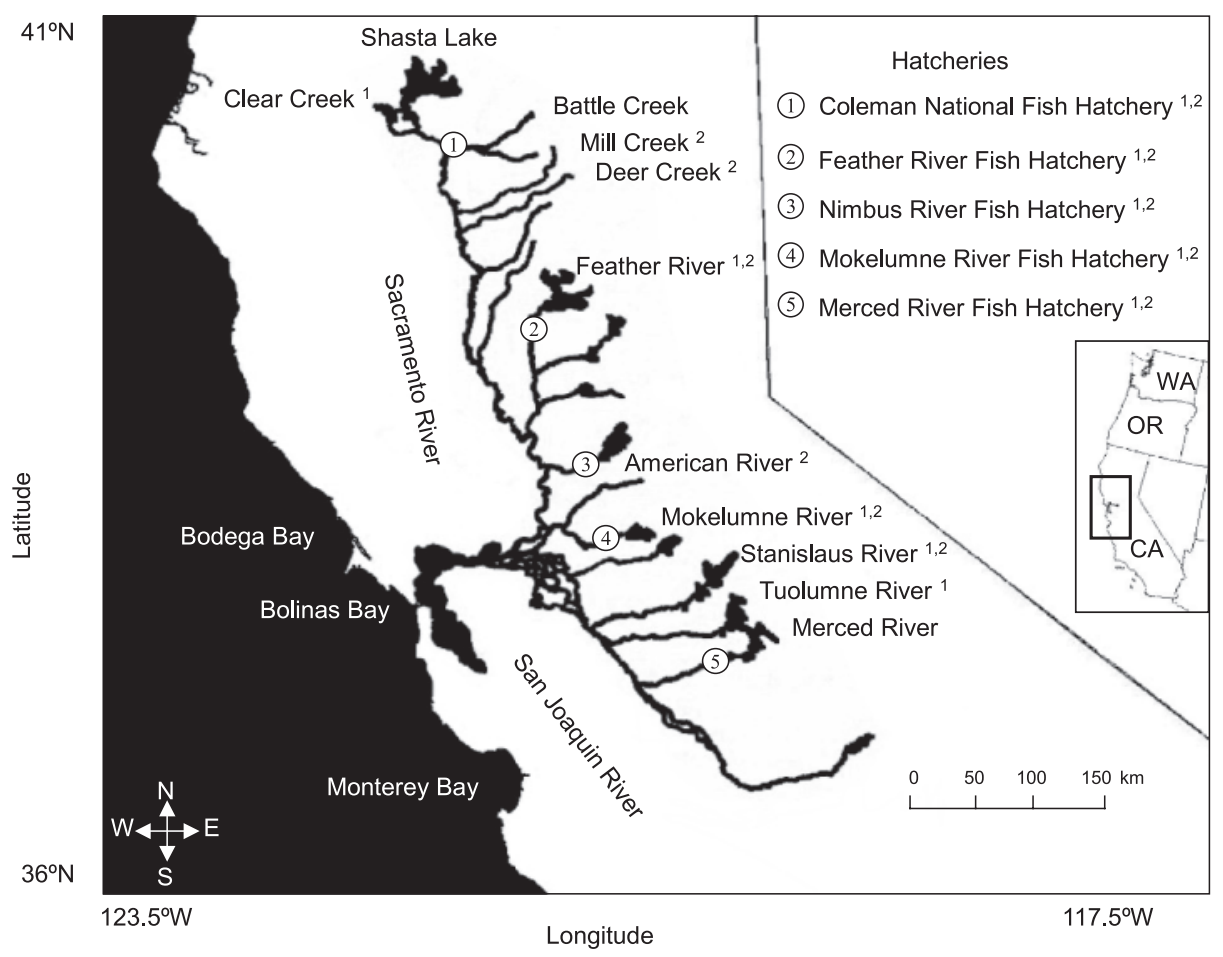

with distilled water to remove soft tissue and stored dry in vials prior to mounting. The left otolith was mounted on a glass microscope slide in thermoplastic resin (CrystalBond $509^{\circledR}$ ) with the sulcus side facing up. The right otolith was used if the left otolith exhibited vaterite conformation of calcium carbonate precluding assessment of microstructural features or was damaged in the preparation process. Individuals containing significant vaterite in both otolith pairs were excluded from analysis ( $25 \%$ of juvenile and adult otoliths). Otoliths were polished on both sides using aluminum oxide lapping paper of 30,15 , and $6 \mu \mathrm{m}$ grit successively until the central primordia, as well as daily increments, were exposed. For adult otoliths, the same preparation techniques were used with the additional preliminary step of coarser lapping paper to expose the juvenile growth portion of the otolith. The appearance of the microstructural characteristics improved when adult otoliths were soaked in distilled water for approximately $15 \mathrm{~min}$ prior to measurements under the microscope.

\section{Otolith microstructure}

For each otolith, microstructural features were measured and counted to determine potential differences in otolith formation between hatchery and wild fish. Otolith sections were observed using a compound microscope (20x) under transmitted polarized light, imaged with a digital camera (Nikon DXM1200 ${ }^{\circledR}$ ), and analyzed with the aid of image analysis software (Optimas ${ }^{\circledR}$ version 6.5, Media Cybernetics, Silver Spring, Maryland) and a customized otolith macro program. Increment widths were measured and enumerated for age determination along a transect $90^{\circ}$ to the longest growth axis, beginning from the most posterior primordium (Fig. 2). This transect was chosen for consistent clarity and lack of small-scale curvature in otolith formation. Widths of 30 daily increments beginning at the exogenous feeding check and progressing toward the margin were measured (Fig. 2). Variability in widths was characterized using the coefficient of variation $(\mathrm{CV})$.

Landmarks of ontogeny such as the hatch check and exogenous feeding check were identified as described by Marshall and Parker (1982) and Zhang et al. (1995) (Fig. 2). A distinct dark band and formation of secondary primordia characterizes the hatch check formed during the transition in development from embryo to fry. Similarly, the exogenous feeding check is identified by a characteristic dark band that forms during the metamorphosis from fry to parr, when the maternal yolk sac is depleted and exogenous feeding begins (Fig. 2). We measured the distances from the posterior primordium to the hatch and exogenous feeding checks along the $90^{\circ}$ transect, referred to above. The prominence of the exogenous feeding check was categorized and scored as not distinct (1), intermediate (1.5), or distinct (2) based on whether it was visible along the entire circumference and isolated from other surrounding dark bands (Fig. 2). Otolith nucleus was characterized as the first growth increment encircling all central otolith primordia and measured as the distance through the longest axis of the nuclear zone (Rybock et al. 1975). The number of primordia was also recorded. In addition, the longest axis, width, and area of the otolith were all measured using the image analysis system. Two readers measured all otoliths without prior knowledge of the origin of juveniles or adults. 
Fig. 2. Differences in the prominence of the exogenous feeding check (arrows) in polished otoliths of $(a)$ wild and $(b)$ hatchery-reared juvenile Chinook salmon (Oncorhynchus tshawytscha). Ninety degree transect line at posterior primordia used for measurements of daily increments ( $\mathrm{D}$, dorsal; $\mathrm{V}$, ventral; P, posterior; A, anterior).

\section{$90^{\circ}$}

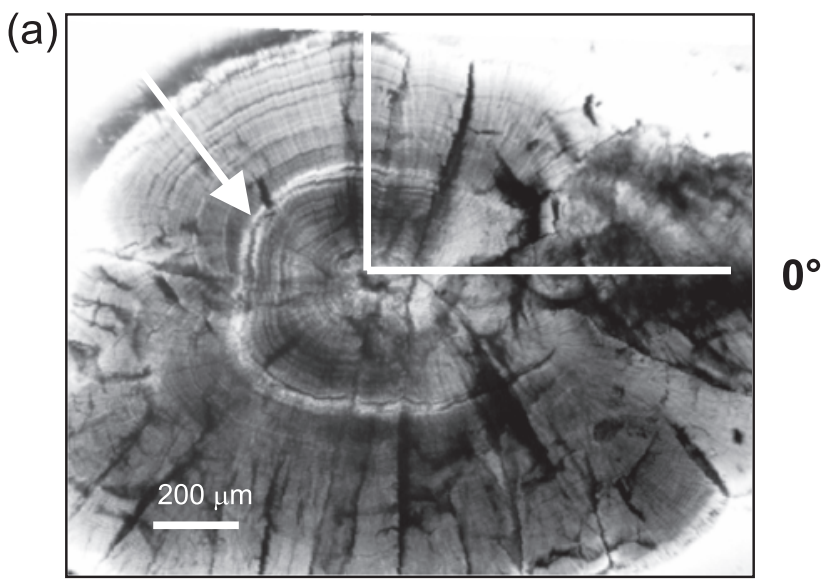

\section{Data analysis}

Otolith measurements from known hatchery and wild juveniles collected in 1999 and 2002 were compared using analysis of variance (ANOVA) to determine whether there were significant differences $(\alpha<0.05)$ in parameters between rearing origins (Table 1 ; mean and coefficient of variation of increment widths, prominence of exogenous feeding check, hatch and exogenous check distance, primordia, and nucleus length). All continuous variables met the assumptions of normality and homogeneity of variances for ANOVAs. Differences in exogenous feeding check scores between hatchery and wild fish were assessed using a twofactor $\chi^{2}$ test ( 2 origin $\times 3$ scores).

Both forward selection and backward elimination techniques for logistic regressions were used to choose the otolith characteristics that best explained the likelihood of belonging to either the hatchery- or wild-origin group (Table 1; SYSTAT ${ }^{\circledR}$ version 10.2, Systat Software, Inc., Point Richmond, California). Linear discriminant function analysis (DFA) was used to determine whether the otolith characteristics retained from the logistic regression model could be used to correctly classify individual fish by rearing origin. Two-way ANOVAs were performed for the three variables retained in the DF models to test for differences between hatchery- and wild-origin fish between years. Based on the categorization of the variables, the models were considered fixed. Scores for the prominence of exogenous feeding check were discrete and did not satisfy the assumption of multivariate normality for DFA. To test the effect of this error structure on the discriminant function classification models, we compared results of DF (where exogenous score was treated as a continuous variable) with results of a contingency table with exogenous feeding as a discrete variable.

Two types of cross-validation approaches (jackknife resampling and independent test data) were used to evaluate four models based on the classification successes of knownorigin wild and hatchery juveniles: $(i)$ jackknife resampling of DFs developed with juveniles collected in 1999, and

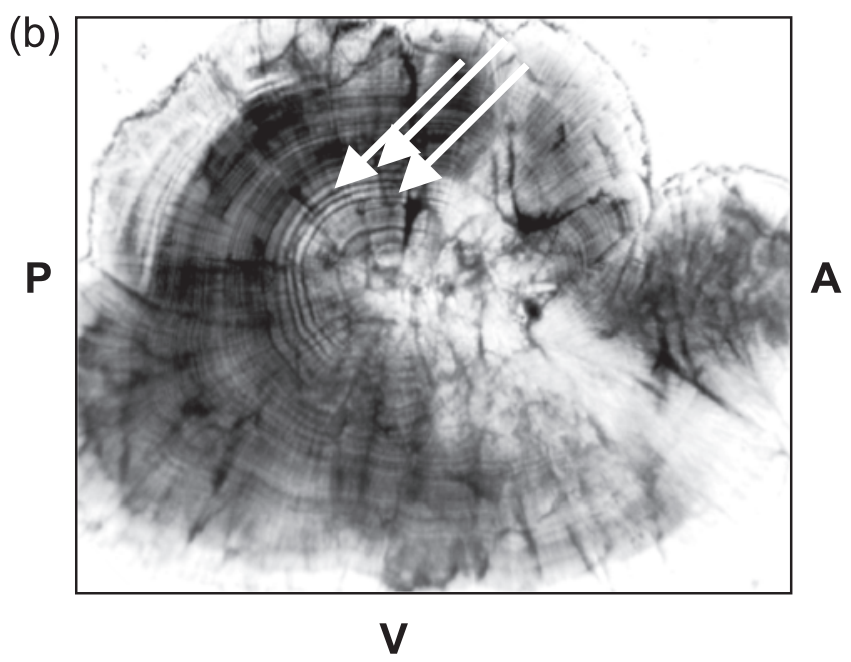

(ii) 2002, (iii) classification of juveniles collected from 2002 (independent test data) using DF developed with juveniles collected in 1999 as a training set (cross-year model), and (iv) jackknife resampling of DF developed by combining juveniles from 1999 and 2002 (combined-year model). Additional evaluations of performance of DFs were conducted using Cohen's $\kappa$, a statistic that provides a method of calculating the chance-corrected percentage of agreement between actual and predicted group classification. Values of $\kappa$ range from 0 to 1 , with 0 indicating that the DF resulted in no improvement over chance, and 1 indicating perfect agreement (Titus et al. 1984).

Performance of the combined-year model on the classification of known-origin adults was used to determine classification estimates appropriate for application to adults collected in the ocean fishery. Known-origin hatchery fish from the CCV were used to estimate the model's ability to correctly classify hatchery adults to rearing origin. Less than $1 \%$ of wild Chinook salmon from the CCV are marked with physical tags, therefore no known wild adults within the same system could be used (CDFG 2001). Alternatively, voucher samples of known-origin wild and hatchery Chinook salmon from Alaska were used as proxies to quantify the ability of the model to identify wild adults.

The rearing origins of Chinook salmon adults in the ocean sample were determined using otolith microstructure data and the combined-year DF model developed from juveniles. However, to estimate the composition of the ocean fishery, we used a maximum likelihood estimation procedure (HISEA) based on finite-mixture distributions rather than deriving the composition by directly classifying individuals with the combined-year DF model (Millar 1987, 1990; Koljonen el al. 2005). The HISEA mixture model (Millar 1990) is more appropriate for this application because unlike DFA, it does not require prior estimates of stock composition. Similar statistical methods have been used to understand stock structure and composition for fisheries applications and assume that the sampled population is representative of the fishery (Pella and 
Table 1. Otolith morphometric measurements and results from one-way analyses of variance (ANOVAs) for hatchery and wild juvenile Chinook salmon sampled in 1999 and 2002.

\begin{tabular}{|c|c|c|c|c|c|c|}
\hline Otolith morphometric & Hatchery & Wild & MS & df & $F$ & $P$ \\
\hline \multicolumn{7}{|l|}{1999} \\
\hline Mean increment width $(\mu \mathrm{m})$ & $2.91(0.38)$ & $2.49(0.29)$ & 3.9 & 1,86 & 34.8 & $<0.0001$ \\
\hline $\mathrm{CV}$ increment width & $0.14(0.02)$ & $0.16(0.03)$ & 0.0 & 1,86 & 21.2 & $<0.0001$ \\
\hline Prominence of exogenous check ${ }^{a}$ & 1.2 & 1.9 & - & 2 & $59.5^{b}$ & $<0.0001$ \\
\hline Hatch check distance $(\mu \mathrm{m})$ & $98.4(7.40)$ & $97.5(8.9)$ & 15.2 & 1,86 & 0.2 & 0.64 \\
\hline Exogenous check distance $(\mu \mathrm{m})$ & $235(20.0)$ & $239.4(17.7)$ & 381.6 & 1,86 & 1.1 & 0.30 \\
\hline Primordia (number) & $6.9(3.5)$ & $8.0(3.3)$ & 24.4 & 1,74 & 2.1 & 0.15 \\
\hline Nucleus length $(\mu \mathrm{m})$ & $281.3(42.2)$ & $313.5(41.8)$ & 24189.9 & 1,92 & 13.7 & $<0.0001$ \\
\hline Age $(\text { days })^{c}$ & $128(23)$ & $124(20)$ & 274.9 & 1,74 & 0.6 & 0.43 \\
\hline Fork length $(\mathrm{mm})^{c}$ & $79(14)$ & $68(15)$ & 2075.5 & 1,66 & 9.7 & 0.003 \\
\hline Fish weight $(\mathrm{g})^{c}$ & $6.1(2.7)$ & $4.2(2.5)$ & 68.5 & 1,81 & 10.2 & 0.002 \\
\hline Otolith length $(\mu \mathrm{m})^{c}$ & $1816(280)$ & $1634(242)$ & 585770.3 & 1,71 & 8.8 & 0.004 \\
\hline Otolith radius $(\mu \mathrm{m})^{c}$ & $558(71)$ & $501(88)$ & 53669.8 & 1,52 & 6.4 & 0.014 \\
\hline \multicolumn{7}{|l|}{2002} \\
\hline Mean increment width $(\mu \mathrm{m})$ & $2.86(0.28)$ & $2.5(0.46)$ & 1.8 & 1,56 & 11.6 & 0.001 \\
\hline $\mathrm{CV}$ increment width & $0.15(0.03)$ & $0.20(0.06)$ & 0.0 & 1,56 & 11.9 & 0.001 \\
\hline Prominence of exogenous check ${ }^{a}$ & 1.1 & 1.9 & - & 2 & $35.4^{b}$ & $<0.0001$ \\
\hline Hatch check distance $(\mu \mathrm{m})$ & $94.8(11.1)$ & $92.5(10.4)$ & 80.2 & 1,56 & 0.7 & 0.407 \\
\hline Exogenous check distance $(\mu \mathrm{m})$ & $241.5(16.4)$ & $240.6(16.8)$ & 11.3 & 1,56 & 0.0 & 0.840 \\
\hline Primordia (number) & $6.1(3.4)$ & $7.2(3.0)$ & 17.4 & 1,54 & 1.7 & 0.194 \\
\hline Nucleus length $(\mu \mathrm{m})$ & $344.9(99.8)$ & $356.7(119.5)$ & 20009.1 & 1,56 & 0.2 & 0.689 \\
\hline Age (days) & $127(16)$ & $130(24)$ & 113.9 & 1,56 & 0.3 & 0.610 \\
\hline Fork length (mm) & $70.7(10.2)$ & $71.1(12.5)$ & 2.8 & 1,53 & 0.0 & 0.885 \\
\hline Otolith length $(\mu \mathrm{m})$ & $1544(228)$ & $1546(231)$ & 33.2 & 1,46 & 0.0 & 0.980 \\
\hline Otolith radius $(\mu \mathrm{m})$ & $470(70)$ & $444(60)$ & 9054.9 & 1,55 & 2.2 & 0.143 \\
\hline
\end{tabular}

Note: CV, coefficient of variation; morphometric measurements represent means (1 standard deviation, SD).

${ }^{a} \mathrm{SD}$ not presented for discrete variables.

${ }^{b}$ Chi-square.

${ }^{c}$ Older fish sampled in the San Francisco Estuary excluded.

Robertson 1979; DeVries et al. 2002; Fabrizio 2005). Standard errors on the estimated proportions of hatchery and wild fish to the salmon fishery off the central California coast were obtained through bootstrapping with 500 replicates (Millar 1990). This term includes error associated with the classification algorithm and estimates the population composition of the fishery from our sample data.

\section{Results}

Several otolith morphometrics differed significantly between wild and hatchery juvenile salmon. Daily growth increments formed in otoliths of wild Chinook salmon immediately after the onset of exogenous feeding were narrower and less uniform in width relative to those of hatchery fish (Fig. 3). Mean increment width was 1.2 times greater in hatchery fish than wild fish in both 1999 and 2002 (Table 1). Mean variation $(\mathrm{CV})$ in increment widths was lower in hatchery than wild fish (Fig. 3; Table 1). Otoliths of hatchery fish did not contain as distinct an exogenous feeding check as found in otoliths of most wild fish (Table 1). The remaining otolith microstructural features examined (hatch check distance, exogenous check distance, primorida, nucleus length, age, length, and radius) were either omitted from further model development based on not differing be- tween hatchery and wild fish or could not be measured in adult otoliths (Table 1).

The exogenous feeding check was more prominent in juveniles of wild origin, and mean and $\mathrm{CV}$ of increment widths were significantly different for hatchery and wild fish. Such differences were consistent over both years sampled (i.e., no significant main effect by year interaction in the two-factor ANOVA; Table 2). In contrast to mean increment widths and prominence of exogenous feeding checks, CVs differed among years, with higher values in 2002 for both hatchery and wild fish (Table 2).

The logistic regression model including prominence of exogenous feeding check, mean, and CV of daily increment widths explained $66 \%$ of the variation in rearing origin. Identification of the two rearing origins relied primarily on the difference in the scores of the exogenous feeding check (54\%, single-variable model), whereas the mean and CV provided additional criteria in the model, particularly when an intermediate exogenous feeding score was determined. All three variables contributed independently to the model and were used in all DFs. Association of the exogenous feeding check scores by rearing origin produced results similar to those of the DFs, suggesting the robustness of the DFA to the non-normal distribution of scores for the prominence of the exogenous feeding check in the model. 
Fig. 3. (a) Dorso-posterior quadrant of an otolith from a wild juvenile Chinook salmon (Oncorhynchus tshawytscha) and (b) narrow and variable widths of the first 30 increments (short lines) postexogenous check (arrow) along $90^{\circ}$ transect (line) relative to the longest axis beginning with most posterior primordia (circle).

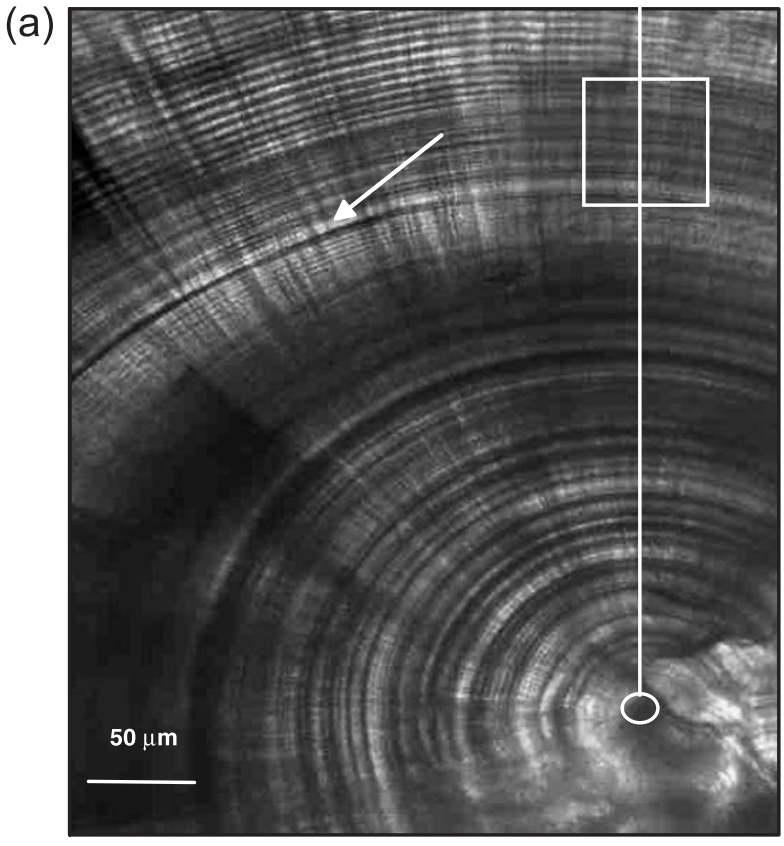

Table 2. Two-factor $\chi^{2}$ results of association of prominence of exogenous feeding check with origin (hatchery vs. wild) and year (1999 and 2002).

\begin{tabular}{llcc}
\hline Otolith morphometric & $\mathrm{df}$ & $\chi^{2}$ or $F$ & $P$ \\
\hline Exogenous check & & & \\
$\quad$ Origin & 2 & 92.5 & $<0.0001$ \\
$\quad$ Year & 2 & 1.1 & 0.57 \\
$\quad$ Widths of increments & 1,142 & 40.4 & $<0.001$ \\
$\quad$ Origin & 1,142 & 0.09 & 0.76 \\
$\quad$ Year & 1,142 & 0.30 & 0.58 \\
$\quad$ Origin $\times$ year & & & \\
Coefficient of variation & \\
$\quad$ & 1,142 & 31.66 & $<0.001$ \\
$\quad$ Origin & 1,142 & 14.99 & $<0.001$ \\
$\quad$ Year & 1,142 & 1.93 & 0.17 \\
$\quad$ Origin $\times$ year &
\end{tabular}

${ }^{a}$ Coefficient of variation of increment widths. Two-way analyses of variance (ANOVAs) for effect of origin and year on mean width and variability of daily increments. Variables were pooled across year and used in final linear discriminant function analysis (DFA) classification model.

Results from DF models using known-origin juveniles suggest that the prominence of exogenous feeding check and mean and variability in daily increment widths can be used in combination as natural tags to determine the rearing origin with high classification success (Table 3). Overall, 93\% of juveniles collected in 1999 were correctly assigned to either hatchery or wild origin using the standard jackknife resampling approach. Fewer juveniles were correctly classified from the 2002 cohort using the standard jackknife resampling (86\%; Table 3). Moreover, the classification success of the 2002 cohort did not change significantly when assigned using the DF developed from fish collected in 1999, suggesting that otolith microstructural features used in calculating the DFs show low interannual variability. Based (b)

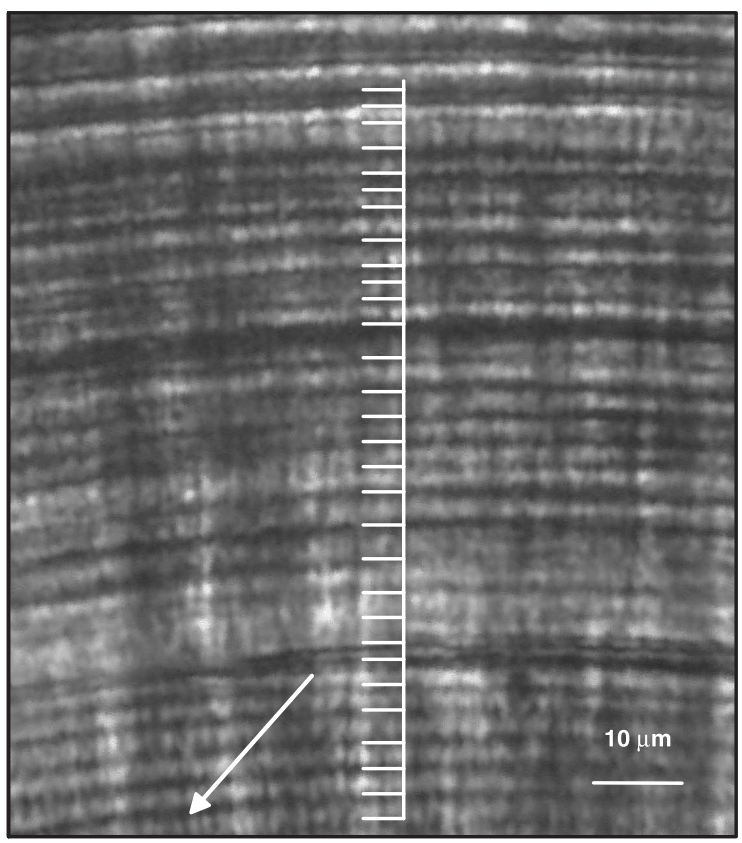

on this, all three variables were pooled across years. Performance of the combined-year DF based on juveniles from 1999 and 2002 resulted in $88 \%$ of hatchery and $94 \%$ of wild fish correctly classified (Table 3 ). Estimates of Cohen's $\kappa$ indicate that the improvement over chance for the combined DF is $82 \%$, with $95 \%$ confidence limits between $72 \%$ and 91\% (Table 3). Histograms of canonical scores from the combined model highlight the separate distributions of hatchery and wild juveniles used in assigning rearing origin of adults (Fig. 4).

Independent validation of the combined-year DF showed that classification success of known-origin hatchery adults from the CCV was also high (90\%). Of the 20 CWT adults, 18 were correctly identified as hatchery fish when blindly analyzed in a mixed sample. Similarly, 90\% of the hatchery fish from Alaska were correctly classified. Identification of wild adults from Alaska confirmed our ability to prepare and detect wild adults (75\%; Table 3). In addition, classification rates of hatchery adults of known origin from the CCV were similar to those of juveniles $(>90 \%)$, suggesting that our method works equally well for both life history stages.

The estimated percentage of wild fish in the mixed-stock fishery along the central California Coast using a maximum likelihood HISEA estimation procedure was $9.8 \%$, with the remainder $(90.2 \%)$ from hatchery sources. The associated standard deviation derived for this population estimate derived from a bootstrap of our sample data with 500 replications was $6.3 \%$. A bias-corrected $90 \%$ confidence interval was not calculated given the symmetry in classification errors of hatchery and wild juveniles.

\section{Discussion}

We demonstrate that variation in otolith microstructure and prominence of the exogenous feeding check, in particu- 
Table 3. Classification of known hatchery or wild-origin Chinook salmon.

\begin{tabular}{|c|c|c|c|c|c|}
\hline \multirow[b]{2}{*}{ Samples } & \multirow[b]{2}{*}{$N$} & \multirow[b]{2}{*}{ DF model } & \multicolumn{2}{|c|}{ Correct $(\%)$} & \multirow[b]{2}{*}{ Cohen's к $(95 \% \mathrm{CI})$} \\
\hline & & & Hatchery & Wild & \\
\hline \multicolumn{6}{|l|}{ Juveniles } \\
\hline 1999 & 90 & Jackknife 1999 & 90 & 96 & $0.86(0.75-0.97)$ \\
\hline 2002 & 58 & Jackknife 2002 & 84 & 88 & $0.72(0.53-0.90)$ \\
\hline 2002 & 90 & Cross years (1999 juveniles) & 84 & 90 & $0.75(0.58-0.93)$ \\
\hline $1999+2002$ & 148 & Combined years (Jackknife) & 88 & 94 & $0.82(0.72-0.91)$ \\
\hline \multicolumn{6}{|l|}{ Adults } \\
\hline California Central Valley & 20 & Combined years & 90 & - & - \\
\hline Alaska & 22 & Combined years & 90 & 75 & $0.64(0.31-0.97)$ \\
\hline
\end{tabular}

Note: All linear discriminant function models (DF) used mean and variability in increment widths and prominence of exogenous feeding check as predictor variables. CI, confidence interval.

Fig. 4. Frequency histogram of canonical scores for hatchery (solid bars) and wild (shaded bars) Chinook salmon (Oncorhynchus tshawytscha). Individuals with canonical scores within respective distributions relative to zero value (vertical broken line) are correctly classified by combined 1999 and 2002 linear discriminant function analysis (DFA) model.

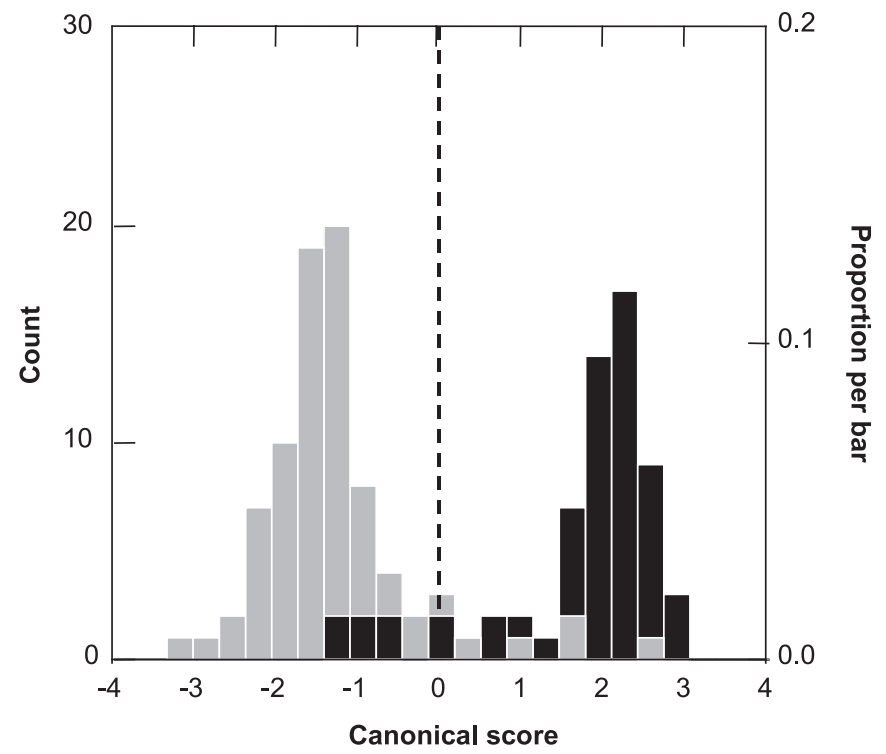

lar, can be used to identify hatchery- and wild-origin Chinook salmon across years with high accuracy ( $91 \%)$ and rapid assessment throughout the broad species' range. Our application to the California mixed-stock ocean fishery provides the first independent assessment of the contribution of wild fish, an application that currently eludes alternative tagging methods (e.g., CWT) within the system. The previously undetected low contribution of wild Chinook salmon to the fishery off central California $(10 \% \pm 6 \%)$ demonstrates the utility of this technique for the majority of other systems where the status and trends of wild fish cannot be quantified independently from hatchery supplementation.

Otolith microstructure pattern is known to be influenced by environmental factors such as temperature, amount of food, and feeding frequency (Neilson and Geen 1982; Campana and Neilson 1985). To the extent that hatcheries and natural environments differ in environmental variables related to growth, otolith microstructures can be used as natu- ral tags to identify rearing origins of individuals. Several studies have demonstrated that morphological characteristics of hatchery fish are more homogeneous across a large geographical range than are those of wild fish in the same range (Hjort and Schreck 1982; Taylor 1986; Fleming and Gross 1989), indicating the potential for broad utility of the otolith microstructure technique to identify rearing origin.

In particular, differences in food abundance and constancy in hatcheries and rivers can affect growth rates differentially, resulting in different widths and patterns of variation of daily increments in otoliths observed in the two rearing environments. Hatchery Chinook salmon, in general, and Chinook salmon from CCV hatcheries, in particular, are fed liberally on a daily schedule, resulting in faster fish growth and wider, more uniform daily increments. Conversely, wild Chinook salmon experience more limited and more variable food supply creating narrow and irregular daily increments.

A distinct exogenous feeding check from discontinuity in increment formation was found more frequently in wild salmon than in hatchery fish. Check production in otoliths is often associated with physiological stress (Payan et al. 2004). Checks form commonly between life history transitions, such as settlement of larval fish into benthic habitats and changes in food consumption (Victor 1982; Campana and Neilson 1985). Recently hatched salmonids rear in benthic stream habitats and feed on maternally derived yolk for several months before exhausting this food resource and commencing exogenous feeding in the water column on invertebrates. This transition can induce a check in the otoliths of wild salmon marking the transition from passive feeding on predictable reserves to active foraging on more variable prey (Skoglund and Barlaup 2006). In extrapolating optimal foraging theory to salmonids, juveniles would exhaust maternal resources prior to adopting foraging behavior to maximize energy and minimize predation risk (Stephens and Krebs 1986). Foraging environments for hatchery fish differ from those of wild fish in that abundant artificial food is made available before the exhaustion of yolk (Terry West, Nimbus Hatchery, 2001 Nimbus Road, Rancho Cordova, CA 95670, USA, personal communication, 2006). Chinook salmon with yolk sacs have been observed feeding on hatchery feed, thereby potentially dampening the stress of transition between the two resource acquisition stages and resulting in a less prominent check in the otolith (Titus et al. 2004). 
The most important variable used to distinguish wild from hatchery Chinook salmon is the prominence of the exogenous feeding check. Ninety-four percent of otoliths from our wild juveniles had a distinct exogenous feeding check, whereas a small proportion (6\%) did not and, consequently, were misclassified as hatchery-reared. This result may suggest that the majority of wild fish experienced this abrupt transition in food resources, whereas $6 \%$ of wild fish may have transitioned to exogenous feeding smoothly or begun exogenous feeding before complete yolk absorption. Our interpretation is supported by findings by Skoglund and Barlaup (2006) on the foraging behavior of brown trout (Salmo trutta) that the majority of wild fish initiated exogenous feeding after they emerged from the gravel with no yolk, whereas a small fraction of fish began foraging with yolk reserves. Eighty-eight percent of hatchery fish had no distinct check, suggesting that $12 \%$ may have exhausted yolk resources prior to feeding, resulting in a check in the otolith. In most cases of misclassification, individuals had exogenous feeding check characteristics of the opposing rearing type.

Previous studies have used differences in otolith shape and microstructure among fish stocks as natural tags, demonstrating the utility of this technique for mixed-stock fisheries analyses (Campana and Casselman 1993; Friedland and Reddin 1994; DeVries et al. 2002). In particular, using variation in otolith increment widths, Zhang et al. (1995) identified hatchery and wild Chinook salmon from the Cowichan River in British Columbia with $89 \%$ accuracy in adults. Average increment widths and ranges in coefficients of variation for hatchery and wild juvenile salmon in their study were $3.97 \mu \mathrm{m}(\mathrm{CV}$ range $0.06-0.17)$ and $2.37 \mu \mathrm{m}(\mathrm{CV}$ range 0.25-0.41), respectively (Zhang et al. 1995). Both the Zhang et al. (1995) study and our study show increased width and uniformity in increments in otoliths for hatchery salmon. Although Chinook salmon from the CCV are the most southern population in the species distribution, wild $\mathrm{CCV}$ fish had values for widths and variation in daily increment widths $(2.5 \mu \mathrm{m}$ and $\mathrm{CV}=0.18)$ similar to those of wild fish from Cowichan River $(2.4 \mu \mathrm{m}$ and $\mathrm{CV}=0.16)$, which is much further north. However, hatchery fish from the CCV had narrower and less uniform increment widths than otoliths from fish from the Cowichan River system. This may be due to the use of warmer groundwater in the Cowichan River hatchery and differences in food used in many hatcheries in Canada (Zhang et al. 1995; Terry West, Nimbus Hatchery, 2001 Nimbus Road, Rancho Cordova, CA 95670, USA, personal communication, 2006).

Application of our DF model to previously published otolith microstructure data from British Columbia suggests that the model is geographically robust. Zhang et al. (1995) provided data of widths and variability of increments but did not document the prominence of exogenous feeding checks between hatchery and wild fish. By modifying our combined DF model by using our means and CVs of daily increments only, our classification model correctly identified $100 \%$ of hatchery and wild juveniles from Cowichan River and hatchery (fig. 6 in Zhang et al. (1995); $N=100$ ). These results suggest that differences in hatchery and wild otoliths may be a general feature and particularly robust in its demonstration in California, as temperature differences between hatchery and wild environments would likely be minimized at the southern extent of the Chinook salmon range, potentially lessening microstructural differences.

Various factors could potentially bias our estimates of the contribution of wild salmon in the fishery. Removal of vateritic otoliths from our analysis may have resulted in an overestimate of the contribution of wild fish to the ocean fishery, if a higher proportion of hatchery fish have vateritic otoliths as demonstrated in other studies (Sweeting et al. 2004). However, of the 1020 hatchery and wild juvenile otoliths collected between 1999 and 2002, there was no significant difference between the occurrence of vaterite in otoliths of hatchery- versus wild-origin fish in the CCV $\left(\chi^{2}=0.16\right.$, $N=1020$, df $=1, p=0.90 ;$ Barnett-Johnson 2007).

Our estimate of $10 \% \pm 6 \%$ wild salmon is the first independent estimate of the contribution of wild Chinook salmon to the central California ocean fishery. This estimate differs considerably from estimates of the relative contribution of naturally spawned fish to mixed populations within the $\mathrm{CCV}$ based on escapement data. According to Cramer (1989), the total hatchery contribution to the fall run of Chinook salmon on the Sacramento River for 1978-1987 was only 33\%, and hatchery proportions in spawning escapement were $26 \%$ in the Feather River and 29\% in the American River. Additional estimates of natural and hatchery escapements on several rivers throughout the $\mathrm{CCV}$ indicate that natural production (numbers of individuals naturally spawning) in 2003 were 3.5 times greater than adults spawned in hatcheries (PFMC 2004). Our results indicate that hatchery supplementation $(\sim 90 \%)$ is playing a larger role than previously thought.

Our estimate of $10 \%$ wild salmon in the ocean fishery refers to fish that reared in natural habitats as juveniles. It should be noted that fish classified as "wild" in our study could be the progeny of hatchery-reared fish that spawned in the wild. Therefore, the estimate of $10 \%$ wild fish in the ocean fishery includes an unknown but potentially large contribution of juveniles from hatchery-origin adults spawning in the rivers. The exact contribution of these hatchery-produced adults could be assessed by applying our approach to identify the origin of carcasses of spawned adults. One benefit of this approach over traditional CWT for this application is that only a small fraction of the spawning population needs to be analyzed rather than surveying large populations to recover physical tags. More precise estimates of the contribution of hatchery and wild fish are possible using analysis of sulfur isotopes in otoliths (Weber et al. 2002), but the numbers of samples are limited because of higher analytical costs.

Given the low contribution of wild fish to the central California coastal fishery, it is particularly important to routinely monitor the status and trends of wild salmon. Other studies reported that hatchery fish have replaced wild fish in the ocean (Pearcy 1997; Unwin and Glova 1997; Hilborn and Eggers 2000). Estimates of the contribution of wild CCV fall Chinook salmon to the ocean fishery off central California have been challenging because of the small and variable fraction of hatchery fish marked with CWTs among years, creating significant errors when extrapolating to population estimates (CDFG 2001; Alan Grover, California Department of Fish and Game, Ocean Salmon Project, 475 Aviation Boulevard, Suite 130, Santa Rosa, CA 95403, USA, personal communication, 2001). Additionally, these estimates gener- 
ally assume equal survival of hatchery and naturally reared fish. Yet, survival rates for hatchery fish have been shown to differ from those for wild fish with conflicting evidence as to the magnitude and directionality of effect. Survival of hatchery fish has been reported to be lower (Bachman 1984; Berg and Jorgensen 1991; Lichatowich 1999), higher (Berejikian et al. 1999; Reinhardt et al. 2001), or similar (Rhodes and Quinn 1999) to that of wild fish. Research in Puget Sound shows that survivorship of hatchery fish can be lower than that of wild fish, causing underestimates of the abundance of wild fish (Lichatowich 1999).

This study provides a direct and practical technique for identifying hatchery and wild Chinook salmon using otolith microstructure as natural tags. Our model allowed for identification of hatchery and wild Chinook salmon from CCV, Alaska, and British Columbia, suggesting that hatchery practices may be similar and create environments different enough from natural environments that otolith microstructure could be used as natural tags throughout the broad species' range. Furthermore, the ability of the DF to correctly assign individuals to rearing origin based on prominence of exogenous feeding check and mean and variability in daily increments in the CCV between years demonstrates that these tags are temporally robust. In addition, otoliths can be efficiently prepared for viewing the prominence of the exogenous feeding check, which is easy to score and can be used alone in a $\chi^{2}$ analysis to produce classification rates of $89 \%$ hatchery $(N=55)$ and $95 \%$ wild $(N=75)$ origin, omitting individuals with intermediate scores of $1.5(N=16)$ that were from hatchery- and wild-origin equally, thereby increasing the utility of this technique for rapid classification for fisheries applications.

Central Valley fall-run Chinook salmon has been assigned candidate status for listing under the US Endangered Species Act (ESA), in part because of the unknown status of wild populations (Myers et al. 1998). Use of otolith microstructure as natural tags allowed us to conduct an independent assessment of the contribution of wild fish to the fishery, which had remained unquantified. An estimate of the relative contribution can be used to quantify population trends to assist in the status designation under the ESA when assessed over time and with the use of population abundance estimates of either hatchery or wild fish using traditional tagging methods. Independent assessments of hatchery and wild populations are important in understanding how hatchery and wild salmon contribute to their combined population dynamics, their relative responses to environmental variation, and interactions between the two sources.

\section{Acknowledgements}

We thank J. Alonzo, C. Arrison, R. Brown, B. Cavallo, M. Cozart, D. Demko, I. Drury, S. Hamelberg, T. Heyne, A. Kastner, J. Kindopp, R. Kurth, J. Merz, A. Phillips, A. Quinones, T. West, M. Workman, and S.P. Crammer \& Associates for juvenile samples; P. Parravano, J. Hie, R. Block, Dave's Albacore, and M. Kilgour for the adult ocean sample collection; D. Oxman for Alaska samples; M. Heisdorf, R. Rickert, M. Erickson, and P. Brandes for CWT tag data; and A. Nickels and B. Tanner for sample preparation assistance. This work was supported by the University of California Marine Coun- cil's Coastal Environmental Quality Initiative (CEQI), Myers Oceanographic Trust, and the Partnership for Interdisciplinary Studies of Coastal Oceans (PISCO; funded by the David and Lucile Packard Foundation and the Gordon and Betty Moore Foundation; contribution number 248). We are grateful to R.B. MacFarlane, M. Carr, P. Raimondi, P. Koch, A. Grover, and two anonymous reviewers for thoughtful improvements to the manuscript.

\section{References}

Araki, H., Cooper, B., and Blouin, M.S. 2007. Genetic effects of captive breeding cause a rapid, cumulative fitness decline in the wild. Science (Washington, D.C.), 318: 100-103.

Bachman, R.A. 1984. Foraging behavior of free-ranging wild and hatchery brown trout in a stream. Trans. Am. Fish. Soc. 113(1): $1-32$.

Banks, M.A., Rashbrook, V.K., Calavetta, M.J., Dean, C.A., and Hedgecock, D. 2000. Analysis of microsatellite DNA resolves genetic structure and diversity of Chinook salmon (Oncorhynchus tshawytscha) in California's Central Valley. Can. J. Fish. Aquat. Sci. 57(5): 915-927.

Barnett-Johnson, R. 2007. Spatial scales of mixing and natal source contributions of salmon populations in the coastal ocean detected by otolith and genetic signatures of origin. Ph.D. thesis, Department of Ecology and Evolutionary Biology, The University of California - Santa Cruz, Santa Cruz, Calif.

Berejikian, B.A., Tezak, E.P., Schroder, S.L., Flagg, T.A., and Knudsen, C.M. 1999. Competitive differences between newly emerged offspring of captive-reared and wild coho salmon. Trans. Am. Fish. Soc. 128(5): 832-839.

Berg, S., and Jorgensen, J. 1991. Stocking experiments with 0+ and 1+ trout parr, Salmo trutta L., of wild and hatchery origin.1. Post-stocking mortality and smolt yield. J. Fish Biol. 39(2): 151-169.

Brannon, E.L., Amend, D.F., Cronin, M.A., Lannan, J.E., LaPatra, S., McNeil, W.J., Nobel, R.E., Smith, C.E., Talbot, A.J., Wedemeyer, G.A., and Westers, H. 2004. The controversy about salmon hatcheries. Fisheries, 29(9): 12-31.

California Department of Fish and Game. 2001. Final report on anadromous salmonids fish hatcheries in California. California Department of Fish and Game and the National Marine Fisheries Service Southwest Region Joint Hatchery Review Committee. Available from the National Marine Fisheries Service, Santa Cruz Laboratory Library, 110 Shaffer Road, Santa Cruz, CA 95060, USA.

Campana, S.E., and Casselman, J.M. 1993. Stock discrimination using otolith shape analysis. Can. J. Fish. Aquat. Sci. 50(5): 1062-1083.

Campana, S.E., and Neilson, J.D. 1985. Microstructure of fish otoliths. Can. J. Fish. Aquat. Sci. 42(5): 1014-1032.

Cramer, S.P. 1989. Contribution of Sacramento Basin hatcheries to ocean catch and river escapement of fall chinook salmon. Available from S.P. Cramer and Associates, Inc., 300 S.E. Arrow Creek Land, Gresham, OR 97080, USA.

DeVries, D.A., Grimes, C.B., and Prager, M.H. 2002. Using otolith shape analysis to distinguish eastern Gulf of Mexico and Atlantic stocks of king mackerel. Fish. Res. 57(1): 51-62.

Fabrizio, M.C. 2005. Experimental design and sampling strategies for mixed-stock analysis. In Stock identification methods applications in fishery science. Edited by S.X. Cadrin, K.D. Friedland, and J.R. Waldman. Elsevier Academic Press, San Francisco, Calif. pp. 467-498. 
Fleming, I.A., and Gross, M.R. 1989. Evolution of adult female life history and morphology in a Pacific salmon (Coho: Oncorhynchus kisutch). Evolution, 43(1): 141-157.

Friedland, K.D., and Reddin, D.G. 1994. Use of otolith morphology in stock discriminations of Atlantic salmon (Salmo salar). Can. J. Fish. Aquat. Sci. 51(1): 91-98.

Grimes, C.B. 1998. Marine stock enhancement: sound management or techno-arrogance? Fisheries, 23(9): 18-23.

Hilborn, R. 1992. Hatcheries and the future of salmon in the Northwest. Fisheries, 17(1): 5-8.

Hilborn, R., and Eggers, D. 2000. A review of hatchery programs for pink salmon in Prince William Sound and Kodiak Island, Alaska. Trans. Am. Fish. Soc. 129(2): 333-350.

Hjort, R.C., and Schreck, C.B. 1982. Phenotypic differences among stocks of hatchery and wild coho salmon, Oncorhynchus kisutch, in Oregon, Washington, and California. Fish. Bull. 80(1): 105119.

Koljonen, M.L., Pella, J.J., and Mesuda, M. 2005. Classical individual assignments versus mixture modeling to estimate stock proportions in Atlantic salmon (Salmo salar) catches from DNA microsatellite data. Can. J. Fish. Aquat. Sci. 62(9): 2143-2158.

Lichatowich, J. 1999. Salmon without rivers: a history of the Pacific salmon crisis. Island Press, Washington, D.C.

MacCall, A.D. 1989. Against marine fish hatcheries: ironies of fishery politics in the technological era. CalCOFI Rep. 30: 46-48.

Marshall, S.L., and Parker, S.S. 1982. Pattern identification in the microstructure of sockeye salmon (Oncorhynchus nerka) otoliths. Can. J. Fish. Aquat. Sci. 39(4): 542-547.

Millar, R.B. 1987. Maximum likelihood estimation of mixed stock fishery composition. Can. J. Fish. Aquat. Sci. 44(3): 583-590.

Millar, R.B. 1990. A versatile computer program for mixed-stock fishery composition estimation. Can. Tech. Rep. Fish. Aquat. Sci. No. 1753.

Myers, J.M., Kope, R.G., Bryant, G.J., Teel, D., Leirheimer, L.J., Wainwright, T.C., Grant, W.S., Waknitz, F.W., Neely, K., Lindley, S.T., and Waples, T.S. 1998. Status review of chinook salmon from Washington, Idaho, Oregon, and California. US Department of Commerce, NOAA Tech Memo. No. NMFS-NWFSC-35.

Myers, R.A., Levin, S.A., Lande, R., James, F.C., Murdoch, W.W., and Paine, R.T. 2004. Hatcheries and endangered salmon. Science (Washington, D.C.), 303(5666): 1980.

National Research Council (NRC). 1996. Upstream: salmon and society in the Pacific Northwest. National Academy Press, Washington, D.C.

Neilson, J.D., and Geen, G.H. 1982. Otoliths of chinook salmon (Oncorhynchus tshawytscha): daily growth increments and factors influencing their production. Can. J. Fish. Aquat. Sci. 39(10): 1340-1347.

Olla, B.L., Davis, M.W., and Ryer, C.H. 1998. Understanding how the hatchery environment represses or promotes the development of behavioral survival skills. Bull. Mar. Sci. 62(2): 531-550.

Pacific Fishery Management Council. 2004. Review of 2003 ocean salmon fisheries. Pacific Fishery Management Council, 7700 NE Ambassador Place, Suite 200, Portland, OR 97220-1384, USA.

Payan, P., De Pontual, H., Edeyer, A., Borelli, G., Boeuf, G., and Mayer-Gostan, N. 2004. Effects of stress on plasma homeostasis, endolymph chemistry, and check formation during otolith growth in rainbow trout (Oncorhynchus mykiss). Can. J. Fish. Aquat. Sci. 61(7): 1247-1255.

Pearcy, W.G. 1997. Salmon production in changing ocean domains. In Pacific salmon and their ecosystems: status and future options. Edited by D.J. Strouder, P.A. Bisson, R.J. Naiman, and M.G. Duke. Chapman and Hall, New York. pp. 331-352.

Pella, J.J., and Robertson, T.L. 1979. Assessment of composition of stock mixtures. Fish. Bull. (U.S.), 77(2): 387-398.

Reinhardt, U.G., Yamamoto, T., and Nakano, S. 2001. Effects of body size and predators on intracohort competition in wild and domesticated juvenile salmon in a stream. Ecol. Res. 16(2): 327-334.

Rhodes, J.S., and Quinn, T.P. 1999. Comparative performance of genetically similar hatchery and naturally reared juvenile coho salmon in streams. N. Am. J. Fish. Manag. 19(3): 670-677.

Rybock, J.T., Horton, H.F., and Fessler, J.L. 1975. Use of otoliths to separate juvenile steelhead trout from juvenile rainbow trout. Fish. Bull. (U.S.), 73(3): 654-659.

Skoglund, H., and Barlaup, B.T. 2006. Feeding pattern and diet of first feeding brown trout fry under natural conditions. J. Fish Biol. 68(2): 506-521.

Smith, N.G., Sullivan, P.J., and Rudstam, L.G. 2006. Using otolith microstructure to determine natal origin of Lake Ontario Chinook salmon. Trans. Am. Fish. Soc. 135(4): 909-914.

Stephens, D.W., and Krebs, J.R. 1986. Foraging theory. Princeton University Press, Princeton, N.J.

Sweeting, R.M., Beamish, R.J., and Neville, C.M. 2004. Crystalline otoliths in teleosts: comparisons between hatchery and wild coho salmon (Oncorhynchus kisutch) in the Strait of Georgia. Rev. Fish Biol. Fish. 14(3): 361-369.

Taylor, E.B. 1986. Differences in morphology between wild and hatchery populations of juvenile coho salmon. Prog. Fish. Cult. 48(3): 171-176.

Titus, K., Mosher, J.A., and Williams, B.K. 1984. Chance-corrected classification for use in discriminant analysis: ecological applications. Am. Midl. Nat. 111(1):1-7.

Titus, R.G., Volkoff, M.C., and Snider, W.M. 2004. Use of otolith microstructure to estimate growth rates of juvenile Chinook salmon from a Central Valley, California, stock. Am. Fish. Soc. Symp. 39: 181-202.

Unwin, M.J., and Glova, G.J. 1997. Changes in life history parameters in a naturally spawning population of chinook salmon (Oncorhynchus tshawytscha) associated with releases of hatchery-reared fish. Can. J. Fish. Aquat. Sci. 54(6): 1235-1245.

Victor, B.C. 1982. Daily otolith increments and recruitment in two coral-reef wrasses, Thalassoma bifasciatum and Halichoeres bivittatus. Mar. Biol. 71(2): 203-208.

Weber, P.K., Hutcheon, I.D., McKeegan, K.D., and Ingram, B.L. 2002. Otolith sulfur isotope method to reconstruct salmon (Oncorhynchus tshawytscha) life history. Can. J. Fish. Aquat. Sci. 59(4): 587-592.

Zhang, Z., Beamish, R.J., and Riddell, B.E. 1995. Differences in otolith microstructure between hatchery-reared and wild chinook salmon (Oncorhynchus tshawytscha). Can. J. Fish. Aquat. Sci. 52(2): 344-352. 